A SUMMER'S DREDGING ON THE COAST OF SOUTHERN CALIFORNIA.*

A CONSIDERABLe piece of marine biological exploration was carried on along the coast of southern California during the past summer by the Zoological Department of the University of California. This was made possible financially by the augmentation of University funds that could be devoted to the undertaking chiefly through the efforts and generosity of Mr. H. W. O'Melveny, Mr. J. A. Graves and Mr. Jacob Baruch of Los Angeles; but to numerous other gentlemen and ladies of that city the warmest thanks are due both for financial assistance and for intelligent interest in and encouragement of the work.

The purpose of the undertaking was investigation. As, however, a little formal teaching could be done without greatly increasing the expenditure or hindering the main work of the summer, it was thought best to offer a few courses of instruction. Three of these were consequently given. One in general marine zoology, one in physiology, and a third for students sufficiently advanced to work under guidance on special problems.

The scientific staff, all from the University of California, consisted of:

William E. Ritter, Ph.D., Associate Professor of Zoology, in charge.

J. W. Raymond, B.S., Assistant Professor of Physics, Hydrography and Conchology.

C. A. Kofoid, Ph.D., Assistant Professor of Histology and Embryology, Zoology and Hydrography.

F. W. Bancroft, Ph.D., Instructor in Physiology.

* A portion of the Preliminary Report to the President of the University of California on the Marine Biological Explorations conducted by the Zoological Department of the University on the coast of southern California, during the summer of 1901 .
H. B. Torrey, M.S., Instructor in Zoology.

Alice Robertson, M.S., Le Conte Fellow in Zoology. In charge of the collections.

In addition there were present at the laboratory for longer or shorter periods during the summer, for the prosecution of independent studies :

Mr. W. C. Adler-Mereschkowsky, a Russian diatomist, now of Los Angeles.

T. D. A. Cockerell, Entomologist of New Mexico Agricultural Experiment Station, East Las Vegas, New Mexico.

W. R. Coe, Ph.D., Assistant Professor of Zoology of Sheffield Scientific School, Yale University.

S. J. Holmes, Ph.D., Instructor in Zoology, University of Michigan.

Miss Sarah I. Monks, Instructor in Zoology, State Normal School, Los Angeles.

Miss G. R. Crocker, graduate student, University of California.

Mrs. Ida Oldroyd, Los Angeles, California.

Fourteen persons, mostly teachers of biological subjects in colleges and high schools of California, were enrolled in the elementary courses.

In view of the importance of the field, and the meagerness of previous investigations in it, it seemed best to plan the sum. mer's work as though it were to be the beginning of a detailed biological survey of the coast of California, even though no assurance could be had of the possibility of continuing the work beyond this season.

Such a survey would of necessity comprehend the investigation, not merely. of the life of the area, but as well of the physical conditions under which it exists. It would have to be hydrographic as well as biological. The limitations of the equipment and the force of workers determined what might be undertaken for the summer. Soundings, temperature and specific gravity. determinations, and the character of 
the bottom were practicable on the hydrographic side. Current investigations, fundamental in importance as they are, could be prosecuted to but a very limited extent.

The dredge and trawl were chiefly relied upon in the collecting. For various reasons it was found both impracticable and unwise to attempt deep plankton work to any considerable extent; neither could surface plankton collecting be extensively carried on, though the limited efforts in this direction were productive of interesting and valuable results.

Both the hydrographic and the biological explorations were extended from the shore line to the hundred-fathom curve. 'The general purposes of the summer's undertaking dictated that the explorations should be carried out with as much accuracy and detail as possible within these bathymetric limits, and that the geographical range over which they should extend should be made secondary to this aim. San Pedro was selected as the base of operations, on account both of its central location in the area to be surveyed and its natural advantages as a site for a marine station. The plan was to explore the coast immediately contiguous to this place and then extend the work to the south and north as far as the time would permit. It was hoped before operations began that they might reach to San Diego at the south, Point Conception at the north and various of the islands off the coast. Experience proved, however, the impossibility of accomplishing so much. The areas actually covered are about thirty miles of coast in the vicinity of San Pedro, viz., from Redondo pier on the northwest to. Newport Bay on the southeast; around Santa Catalina Island; and the vicinity of San Diego from the Los Coronados Islands on the south to La Jolla on the north.

The following table, compiled from the field records, shows something of the amount and distribution of the summer's work:

\begin{tabular}{|c|c|c|c|c|c|c|c|}
\hline \multirow[t]{3}{*}{ Locality. } & \multirow[t]{3}{*}{$\begin{array}{c}\text { Sta- } \\
\text { tions. }\end{array}$} & \multicolumn{3}{|c|}{ Hauls. } & \multirow[t]{3}{*}{ Tem. } & \multirow{3}{*}{$\begin{array}{c}\text { Sound- } \\
\text { ings. }\end{array}$} & \multirow[t]{3}{*}{$\begin{array}{c}\text { Sa- } \\
\text { linity }\end{array}$} \\
\hline & & \multicolumn{3}{|c|}{ Dredge or Plankton. } & & & \\
\hline & & Trawl. & Surface. & Deep. & & & \\
\hline San Pedro & 27 & 40 & 66 & 3 & & & \\
\hline Catalina & & & & & & & \\
\hline Island & 17 & 31 & & 4 & & & \\
\hline San Diego & 41 & 88 & & 4 & & & $23-$ \\
\hline Total. & 85 & 159 & 66 & 11 & $194+$ & $170+$ & 19 \\
\hline
\end{tabular}

EQUIPMENT.

Vessel.-The new gasoline launch Elsie, forty feet in length over all, with a 17horse-power engine, was hired for three months, from May 15 to August 15. The boat proved to be excellently adapted for the purpose, although not built for such service. Contrary to the usual practice in the construction of boats of this type, her entire middle and after portions are without cabin, and are consequently available for working space. The hoisting gear was placed in the middle. The after-deck was supplemented by a temporary structure, extending between it and the hoisting winch, to be used for receiving and sorting the contents of the dredge.

One of the most serious obstacles in the way of successful dredging and trawling with a vessel propelled by a gasoline engine is always found in reducing the speed of the boat sufficiently to keep the trawl on the bottom during the towing without unduly weighting the apparatus. The problem was solved in this instance by using a battery instead of the engine's dynamo for exploding the gasoline, and by casting out a sea-anchor under some conditions. HOISTING GEAR AND COLLECTING APPARATUS.

A hand winch was used for handling the collecting apparatus. With this the strength of four men was sufficient for accomplishing the dredging aims of the expedition, although it was found that a 
depth of a hundred fathoms for the dredge, and three hundred fathoms for the deep plankton net, reached about the limits of practicability. Manila rope nine sixteenths of an inch in diameter was used for all the dredging and deep plankton work.

HYDROGRAPHIC APPARATUS.

The sounding apparatus consisted of the ordinary leads of twelve and twenty pounds weight, galvanized steel wire, No. 10, of the American Steel and Wire Company's grading, and a hand reel, used both for paying out and for reeling in, and for registering the depth. The Miller-Casella thermometer was used for all temperatures below the surface. Surface and atmosphere temperatures were mostly taken by an ordinary chemical instrument. The bucket for taking subsurface samples of water consists of a brass tube $47 \mathrm{~mm}$. in diameter and $500 \mathrm{~mm}$.in length. The closed lower end is provided with a valve opening inward. The upper end is open during the descent of the instrument, so that the water may pass freely through it. The bucket is attached to the sounding-line above the lead and thermometer, the line being passed through the length of the tube and the middle of its bottom. The instrument having been sent down to the depth from which the water sample is desired, is then closed by a messenger sent down on the line. The apparatus was not satisfactory, but was the best obtainable under the circumstances. No observations on the composition of the water were attempted, beyond the determination of its specific gravity. For this work the most sensitive hydrometer available was one with a range of scale 1.000 to 1.040. This not being sufficiently accurate for wholly reliable results, the main dependence was placed upon weighing the water samples.

It was, of course, impossible to use either salinometer or scales on board the launch, but precautions were taken not to allow the water samples to remain long in the bottles before being tested. Temperature corrections were made in all cases. The salinity observations are the least satisfactory, probably, of any of the work seriously attempted. The difficulties of this phase of hydrogaphic investigation are well known to all experienced in it; and greater refinement of both appliances and methods than the funds at our disposal this summer would permit would be necessary to make it satisfactory.

\section{THE LOCATION OF STATIONS.}

An essential feature in such a survey as is here contemplated must be a study of the change in the life of particular localities with the passage of time. The displacement of species and groups of species by others through physical or biological influences; their increase in numbers of individuals ; their migrations, etc., are among the most important, but least understood, questions of marine biology. Data for sound generalizations on these questions must meet two general conditions: First, they must be gathered at fairly frequent intervals throughout an entire year at least; second, they must be gathered from the same identical spot, so far as this is possible. The locating and picking up of stations becomes, consequently, a matter of prime importance. After consultation with several experienced hydrographers, particularly to be mentioned being Professor George Davidson, Mr. Otto Von Goldern, U. S. Engineer Corps, and Lieut. Commander G.C.Calkins, U. S. N., it seemed best to depend upon the sextant for this work. It was believed that greater accuracy could be secured than with the compass, and that it would be more practicable and less expensive than the range-pole method. In the hands of Professor Raymond for the first portion of 
the season, and of Professor Kofoid for the second portion, it proved as satisfactory as any method could, I am convinced. The difficulties in the way of making the haul with the dredge or trawl over precisely the desired course were found to be wholly independent of the method of locating the station. Of these, the drift due to wind and current, which frequently renders it impossible to get the dredge to the bottom at precisely the point after this has been located, is the most serious. It was found practicable to approach within fifty yards of a desired point two or three miles off shore at the first trial; and by maneuvering once or twice,giving eareful heed to the currents and wind, the point may be reached almost exactly. This requires, of course, considerable practice with the sextant, and skill in handling the engine and wheel of the boat.

The procedure consists, as is well known, in locating two angles from three points on shore that are shown on the Coast and Geodetic Survey charts and are as near the level of the water as possible, and not near the circumference of a circle the center of which is the observer; and then of plotting the station on the chart by the use of a tracing-paper protractor.

This method could not be used, of course, at any considerable distance from land, nor on a coast devoid of prominent headlands or other permanent conspicuous objects, nor where fogs are prevalent. Within the geographical and bathymetric limits, however, set for the summer's operations, none of these restrictions applied. At no point is the one-hundred-fathom curve more than ten miles off shore; and in only a few places is it more than five or six miles off.

\section{LABORATORY.}

Two small wooden buildings at East San Pedro were rented for the summer and rebuilt to adapt them to the purposes of a laboratory. These buildings were situated on the breakwater near the pier belonging to the Salt Lake, Los Angeles, and Terminal R. R. This location was selected because of its convenience on the one hand to the inner harbor, and on the other to the open sea. On the harbor side a landing for the launch was at hand within a few yards of the laboratory, and the freight and express offices were equally near by. On the ocean side sea water entirely unpolluted by refuse from shore or shipping came to the very door of the laboratory.

Of the two buildings, one, an old bathhouse, was fitted with seven small private rooms for the use of the investigators, though one of these had to be set aside for the library.

The second building, a larger one, was used for the summer-school classes, for storage and for some of the investigators who could not be provided with private rooms. Accommodation was supplied for a class of fifteen students.

The laboratory equipment, consisting of the usual sort for seaside work, as also the library, were sent from the University at Berkeley.

INVESTIGATIONS PROSECUTED AT THE STATION.

'The Classification and Structure of Diatoms': Mr. Wm. Constantin AdLerMERESCHKOWSKY.

'The Peridinium Visitation that took place on the Southern Coast during the Summer': Mr. H. B. TorREy.

'Speciographic and Ecological Studies on the Actinians of the Region': Mr. H. B. Torrey.

'The Systematic Position and Variation of various species of Echinoderms': MIss G. R. CROCKER.

'The Variation and Autotomy of the star-fish Phataria unifascialis': MIss 'SARAh P. Monks. 
'The Nemerteans of the Region': Dr. W. R. CoE.

'The Opisthobranch Molluses of the Region': Professor T. D. A. Cockerell.

'Classification and Distribution of the gastropod and bivalve.Mollusca': ProFESSOR J. W. RAYMOND and MRS. IDA OLDROYD.

'Speciographic and Anatomical Studies on Bryozoa': Miss Alice Robertson.

'The decapod and amphipod Crustacea': DR. S. J. Holmes.

'The Enteropneusta, Studies on Anatomy and Habits': Professor WM. E. RITTER.

'The Ascidians of the Region': ProFESSOR WM. E. RITTER.

'Experimental Studies on the Fertilization of Ciona': Dr. F. W. BANCROFT and Miss Etheltyn Foote.

'Experimental Studies on the Heart Action of Ciona': Dr. F. W. BANCrofr and Mr. C. O. ESTERLY.

'Selection in the Mortality of Hippa due to the Peridinium Visitation': DR. F. W. BANCROFT.

SOME OF THE SCIENTIFIC RESULTS OF THE SUMMER'S WORK.

Hydrographic.-On this side it is not felt that the data collected are sufficient in quantity to warrant any statement about them in a preliminary report, beyond the mere presentation given above, of what was done.

Geological-Biological.-The observations made corroborating the view that Santa Catalina Island has recently been undergoing subsidence have already been published in this journal, October 11, 1901, p. 575 , and need not be repeated.

Special interest, from the biological side, was attached to the exploration of the peculiar 'submarine valleys' that are so characteristic a feature of the coast of California, Lower California and Mexico. As, however, a complete study of them will lead into deeper water (at their seaward ends into at least eight hundred fathoms*) than we were this year fitted to penetrate, and will go beyond the limits to which detailed soundings have been carried by the Coast and Geodetic Survey, our observations are yet too few and fragmentary to warrant any general conclusions. Two points may, however, be mentioned as having been brought out by our work. First, that the bottom deposits of some, at least, of the valleys, for example that at Redondo, even at the distance of several miles from shore, are of a character to prove that close inshore material is carried into them in large quantities. Shore-worn shells of strictly littoral, and even freshwater species; fragments of drift-wood; kelp hold-fasts, of which none grow in the immediate vicinity, etc., were taken in abundance by the dredge. $\dagger$ Second, various species of deep-water fishes, crustaceans and molluscs were taken much nearer shore in these valleys than elsewhere.

The first mentioned observation suggests, though of course does not prove, that the valleys are natural channels through which currents flow, at times at least, from the shore out to deeper water.

*The U. S. S. Albatross, surveying the Monterey submerged valley with a view to its possible termination for a transpacific cable, found 868 fathoms sixteen and one half miles from shore.

$\uparrow$ Professor Davidson gives something on the character of the bottom in most of the valleys, as determined, presumably, by the soundings. This method cannot be relied upon for the detection of such deposits as are here described. It is a suggestive fact, however, that the author mentions, in connection with the Cape Mendocino submerged valley, that "the valley itself has green mud, and yet in two places at depths of three hundred and twenty fathoms broken shells were brought up with gravel." ("The Submerged Valleys of the Coast of California, U. S. A., and of Lower California and Mexico', Proc. Calif. Acad. Sci., 3d ser., Geol., Vol. I., No. 2, 1897.) 
It cannot be doubted that future study will prove these valleys to play an interesting part in the local distribution of marine life, particularly in the bathymetric distribution. Whether currents ever flow through them from the deeper waters toward land or not, certain it is that the temperature and pressure conditions within them are the same as for corresponding depths elsewhere; they must, consequently, form natural roads whereby deeper water species may reach nearer shore than they otherwise would.

\section{BIOLOGICAL.}

Diatomes.-Mr. Adler-Mereschkowsky came to California for the purpose of studying the diatomes of the West American coast. He has already published a list of California species. The summer's work at the San Pedro laboratory resulted,so far as the studies have yet gone, in identifying fifty known species and ten new ones, with one new genus.

But the most fruitful part of Mr. AdlerMereschkowsky's work was that on the endochrome of these organisms. His observations here have led him to conclusions widely different from the prevailing views concerning these bodies.

Protozoa.-There occurred during the summer on the coast of southern California what might be called a Peridinium epidemic, for the people even, who resort in large numbers to many sea-shore points during the summer months, did not escape the noxious effects of the visitation.

No similar occurrence of this organism on the Pacific coast of North America is recorded so far as I am aware. Indeed, inquiry among many old fishermen, and longshore seamen, who have been familiar with the region for many years, elicited the affirmation, in every instance, that such a thing had never before taken place within the period of their acquaintance with the coast. As full a study of the phenomenon was made as the facilities at our command would permit, and the results as brought together by Mr. H. B. Torrey are now with the American Naturalist for publication. A summary only of these results is, consequently, given here:

1. The duration of the visitation of the organism in sufficient quantity to appreciably color the water was from about July 7 to September 1, 1901.

2. The geographical extent of the phenomenon was from Santa Barbara at the north to San Diego at the south, at least (it may have extended farther south, but we have no reports from more southerly points); and in general from the shore out from four to six miles.

3. Nowhere were the organisms distributed uniformly over considerable areas, but were confined more or less completely to bands or strips varying from a few to many meters in width. They extended to the bottom at a depth of six fathoms at least; but the appliances for determining the bathymetric range were not sufficiently accurate to produce wholly reliable results.

4. The color imparted to the water varied from a light brown, where the organisms were in moderate numbers, to a vermilion, where they were in greatest abundance. The red coloration was due to material of this color contained in the nucleus. At night the phosphorescent display, at the slightest agitation of the water, was truly wonderful.

5. The presence of the organisms in such enormous numbers disturbed the biological equilibrium to a marked degree through the whole area. Several species of fishes, crustaceans, holothurians, star-fishes, and molluses, in particular, suffered a severe mortality, and showed various unmistakable evidences of discomfiture.

6. The injurious effects were apparently due entirely to crowding and the contamination of the water. The odor at times on 
the lee shore, and for a considerable distance inland, was very offensive. This was due to the Peridinium itself, and not to animals killed by it. In character it was a modification of the ordinary odor of decomposing organic matter, and was mostly due to the dead organisms cast up on the shore.

7. A considerable list of other species of chlorophyl-bearing dinoflagellates were present in the water mingled with the Peridinium, and these, particularly several species of Ceratium, largely increased in numbers simultaneously with the increase of Peridinium, though to a comparatively slight extent.

8. The only pelagic organism that seemed to take advantage of the great abundance of Peridinium, as a food supply, was Noctiluca, which towards the end of the visitation became abundant, and fed upon the Peridinium in large numbers.

9. But a single species constituted almost the entire mass, this apparently belonging to the genus Gonyaulax Diesig.

10. It was impossible to correlate the enormous multiplication of the organism with any physical or chemical condition of the water. The cause of such a phenomenon remains for future investigation.

Colenterata.-Siphonophores and ctenophores were taken in far greater abundance, as to both species and individuals, in the plankton this year than we have ever before seen in the waters of our western coast. Worthy of mention, also, is the fact that Valella, which at rare intervals appears in enormous abundance on the coast, was found to be throwing off medusa buds in great numbers during May and June.

Whether the richness in pelagic metazoan life, seen not only in the groups here mentioned, but also in the Pteropoda, Heteropoda, Sagitta, Salpa, Doliolum, etc., may have been correlated with the conditions which resulted in the enormous de- velopment of Peridinium, it is impossible to say owing to the lack of data from previous observations.

Perhaps the most interesting observations on the Cœlenterata were those made by Mr. Torrey on the longitudinal fission, from the base oralward, of a species of sagartia.

Echinodermata.-Of the several interesting questions in connection with the speciography and ecology of the echinoderms, which received attention, mention may be made of two. The representatives of this branch of the animal kingdom, the most common and generally distributed over the area in which work was carried on, are an Astropecton (A. erinaceus Gray?) and a Toxopneustes (T. pileolus Ag.?). Few hauls were made anywhere that did not secure specimens of these species, the Toxopneustes being particularly abundant. A single haul of the dredge on Station XIII. off Point Vincente in thirtyfive fathoms brought up about twelve thousand specimens, by a careful estimate, and little else! Now the type of Toxopneustes pileolus is a littoral animal occurring everywhere on rocky shores. The forms dredged are of a different style. They are somewhat flatter, the spines are more slender; and the color is lighter; yet the two grade into each other. It is almost certain that we have here the differentiation of two species in progress and nearly complete, bathymetric range being the chief differentiating factor.

A large quantity of material and considerable data for the further study of this point were gathered. In a somewhat similar way Astropecton is a distinctly bifurcate species. Indeed, one of the forms has sometimes been considered as a Psilaster. Their intergradation is, however, from our summer's observations proved to be complete. Longer spines with intermarginal plates, purplish and bluish color and 
larger-sized individuals, are the characters usually distinctive of $A$. erinaceus. But these all fail to furnish differential marks for many specimens.

With these two forms, contrary to what we find in Toxopneustes, bathymetric range appears to play no part, as they occur together everywhere in from eight to ten fathoms, to the greatest depths reached in our work. We have thus far been unable to correlate these two varieties with any environmental peculiarities whatever. The general distribution of these two species, as contrasted with the restricted distribution of some other species of both Echinoids and Asteroids in this locality, is noteworthy and is all the more interesting when the variability - as contrasted with the lack of variability in other species localized in their distribution-is regarded. Mediaster cequalis Verrill, for example, may be cited as a species of great rigidity in type. The individuals of this species all have the appearance of having been cut out by the same die, so alike are they in form; and having been dipped in the same paint-box, so similar are they in color. This species was taken at only two or three stations, and in any abundance at only one. Such facts as these strongly impress one who comes face to face with them with the scantiness of our knowledge of the deeper meaning of the relation of organisms to their environment.

Miss Monk's studies on Phataria, a starfish remarkable even among its close allies within the family Linckiidæ, for the variability in the number of its rays, and the readiness with which it parts with them and then regenerates them, led to the following results :

1. The observations proved conclusively that the casting off of the rays is, in most cases at least, not accidental, but a true self-amputation.

2. As the breakage usually occurs at some distance from the disk, and as the 'comet' stars are found abundant in nature, it appears as though the autotomy is for the purpose of asexual reproduction, and hence that the severed arm to which no part of the disk adheres has the power of reproducing the entire animal. But absolute certainty on this point is still to be reached.

A species of Antedon closely related to, if not identical with, $A$. rosacea was taken off San Diego in about one hundred fathoms. So far as I am aware, this is the first record of the occurrence of any species of this genus on the Pacific coast north of Panama.

Bryozoa.-Under the name of Ascorhiza Californica, Dr. Walter Fewkes described a new genus and species of Bryozoan dredged by him in Santa Barbara channel in 1886. The colony consisted of a welldefined capitulum, to which the polypides are restricted, and a long, slender, flexible stem. From the general resemblance of the stem to that of Urnatella, the author surmised the species to be related to the Endoprocta. In the capitulum, however, he recognized some resemblance to Alcyonidium. He, consequently, suggested that the form might stand intermediate between the Endoprocta and the Ectoprocta. As he did not, however, make out much about the polypides, he was unable to support the suggestion with much evidence.

Several specimens of this unique species were dredged during the summer, and from these Miss Alice Robertson has been able to establish definitely that its affinities are undoubtedly with Alcyonidium, and thatits resemblances to Urnatella are wholly superficial. It is, nevertheless, a very interesting form, especially in the nature of the stem. Miss Robertson will shortly publish a paper on this and one or two other species of Alcyonidium of the Pacific coast. A noteworthy fact in connection with the 
Bryozoa of the regions worked in during the summer is the great abundance of the Endoproct Ascopodaria macropes. At no other point on our shores have we found this or any other Endoproct very plentiful. At San Pedro, however, nearly every rock one turns over presents a continuous moving field of this or a closely related species.

Mollusca.-No group of marine invertebrates of the Pacific coast of North America has been so extensively studied, systematically, as the shell-bearing mollusca. For this reason, then, if for no other, these animals are of special importance for studies on geographic and bathymetric distribution.

The expedition was fortunate in having for nearly the entire summer two such enthusiastic and well-informed conchologists as Professor Raymond and Mrs. Oldroyd in its membership; and a vast amount, of material was secured, the detailed examination of which is, of course, still far from complete. Some idea of the wealth of the collections in the group may be gained from the statement that in the San Pedro and Santa Catalina Island areas alone two hundred and thirty species, exclusive of the Polyplacophora and Pteropoda, have been identified, and it is certain that the number will be largely increased by more detailed study. A few species are almost certainly new to science, though just how many it is not yet possible to say.

The total number of species of mollusca of the Pacific coast of Canada contained in the list published by Rev. G. W. Taylor in 1897 is two hundred and seventy-nine. The total number in the list of species of 'Los Angeles County, now in course of preparation and nearly complete, by Mrs. Oldroyd, is something over five hundred.

The familiar, though nevertheless striking, general rule of the occurrence in comparatively deep water off shore of species that are strictly littoral to the northward, receives many illustrations in this group. A good example is furnished by Priene oregonensis Redfield, which occurs in a few fathoms at Sitka, Alaska, and was taken this summer in about one hundred fathoms off San Diego. Cryptochiton stelleri, also found in this locality for the first time this year, I believe, is another example of the same sort.

Professor Raymond has elsewhere* expressed the view that Point Conception marks a dividing line between molluscan faunæ to the north and south of it that are quite distinct; and Dall $\nmid$ affirms that Point Conception is the northern limit of the Panamic fauna.

The results of the summer's work, so far as they can yet be seen, confirm these views. To harmonize the apparent fact of this faunal delimitation with the view that the Davidson inshore current flows out of the Santa Barbara channel around Point Conception and then on northward, is only one of the many problems presenting themselves for solution on our coast.

Worthy of note is the discovery made by Mrs. Burton Williamson during the summer while at work at the laboratory, that at least two species of Pecten occurring on the southern coast, viz., $P$. equisulcatus and $P$. diegensis are hermaphroditic. A species of gymnosmatous pteropod related to Pneumodermon pacificum Dall, though probably a different species, was taken with the deep plankton net in San Pedro channel in considerable numbers. No species of this genus, excepting pacificum, has been reported hitherto from the California coast, so far as I have been able to ascertain.

Many of the specimens of a species of

* The California Species of the genus Nuttalina,' Nautilus, Vol. VII., 1894, p. 133.

$\dagger$ 'Synopsis of the Family Tellinidæ and of the North American Species,' Proc. U. S. Nat. Mus., Vol. XXIII., 1900. 
Carinaria, apparently new, taken in considerable abundance off San Pedro, were found to be headless, though still alive and well, thus presenting a condition that has been observed by a number of naturalists in Firola. This decapitate state was so common, and so uniform in character-i. e., as to the size of the portion lost and the character of the wound-that it can hardly be supposed to have been due to mere accident. The meaning of this case is as diffcult to understand as is that of the selfamputation of the posterior third of Prophysaon which has been noted by several observers, and which I have myself seen.

Of the opisthobranch and nudibranch mollusca, about twenty species were recognized in the San Pedro district by Professor Cockerell. Of these, five at least are almost certainly new.

Crustacea.-Of the seventy or more species of decapod crustacea taken at San Pedro during the summer (the San Diego collections have not yet been worked over), five, according to Dr. Holmes' preliminary examinations, are probably new to science, the presumably new forms all coming from deep waters. Among them may be mentioned as of special interest a Pagurid inhabiting the tube of the Annelid Pectinaria.

A noteworthy extension of geographic range in this group is that of three species of Pandalus, viz., P. Dance St., P. pubescentulus Dana, and $P$. franciscorum Kingsley. None of these were before known to occur south of San Francisco and pubescentulus was not known farther south than the coast of Oregon.

The beautiful Navanax ineremis Cooper, which is not uncommon in San Pedro harbor, is the residence of an interesting copepod which has the curious habit of using the slime of its host's external surface not merely for clinging so closely as to make its removal quite difficult, but also as a medium in which to move about with great freedom and rapidity. Professor Cockerell, in particular, gave considerable attention to this curious case of commensalism.

The summer's work brought to light one new Enteropneust, making thus three species representing as many genera, from the San Pedro district. Ptychodera occidentalis Ritter MS. and Dolichoglossus pusillus Ritter MS. occur together in San Pedro inner harbor, while the one now added belonging, apparently, to the restricted genus Balanoglossus, was taken by the dredge in from seventeen to thirty fathoms off Newport, California.

The new species is related to Balanoglossus canadensis. Unfortunately, we were able to get only three specimens.

It is my intention to include the description of this species in my forthcoming monograph of the Enteropneusta of the Pacific coast of North America, now nearly ready for publication, and to appear in the scientific results of the Harriman Alaska Expedition.

About thirty species of simple and compound Ascidians were collected during the summer, the larger proportion of them being taken by the dredge only. At least four of these have not been taken before on the Pacific coast, and are almost certainly new to science. Even the deepest dredging failed to bring to light much of anything in common between the Ascidian fauna of this region and that of the Pacific coast north of Puget Sound. At the present time I identify two species, viz., Amaroucium californicum and Distaplia occidentalis, and possibly a third, Styela montereyensis, as ranging from western Alaska to southern California.

The work of Dr. Bancroft and $\mathrm{Mr}$. Esterly on the heart-beat of Ciona, while still incomplete, arrived at the follow definite conclusions : 
(1) The results confirm those of Schultze that isolated pieces from the center of the heart can contract in sea water. (2) They have established the new facts, $(a)$ that in the intact animal the heart may sometimes beat from the center towards both ends; also, (b) that when the heart is tied near the center, the isolated pieces may sometimes beat from the center towards the ends; and (c) in such pieces there may even be a regular alteration in the direction of the heart-beat. These last results will probably necessitate a complete change in our conception of the character of the Ascidian heart-beat.

This is a proper place to record the occurrence of Branchiostoma Californiense at San Pedro, hitherto not known farther north than San Diego. About a dozen specimens were dredged during the summer, some in the inner harbor, and others outside but near its mouth.

It may also be noted here that the Point Loma blind fish, Typhlogobius Californiensis, hitherto not reported north of San Diego, was found at San Pedro. At White's Point it was found in holes in the soft rock and under stones; while during the Peridinium visitation a considerable number of specimens were cast ashore, some alive and others dead, along. the breakwater at San Pedro.

UNIVERSITY OF CALIFornia,

WM. E. RitTER. BERKELEY, October 29, 1901.

\section{SCIENTIFIC BOOKS.}

A Treatise on Hydraulics. By Henry $\mathrm{T}$. Bovey, M. Inst. C.E., LL.D., F.R.S.C. Second edition, rewritten. New York, John Wiley and Sons. 1901. Pp. xviii +583. Figs.: 330 . Price, $\$ 5.00$.

The second edition of Dr. Bovey's wellknown text-book is practically a new work, having been largely rewritten, rearranged and nearly doubled in extent; forming a very important and valuable addition to the literature of engineering education. It contains 583 pages and 330 figures, as against 337 and 196, respectively, in the first edition; embodying also some improvements in mechanical execution, such as the substitution of clear-cut line engravings for the few (but hazy) half-tones illustrating certain water-meters in the first edition, and the use of bold-faced type for important formulæ. Being printed on thinner paper the present volume possesses no more weight or bulk than the earlier book.

As in the earlier edition, the statements of many numerical examples, with their answers, are placed at the end of each chapter, and these have been greatly increased in number (e. g., at the end of Chapter I. we find $106 \mathrm{ex}$ amples as against 76 in the first edition); but a new and special feature in this respect consists in the insertion, in the body of the text in connection with each topic, of numerical examples fully worked out in all their details. This added feature will be heartily welcomed by engineering students possessing only average mathematical ability, and hence needing careful guidance in the principles of correct numerical substitution.

Among additions to the subject-matter the following are prominent:

A description of the elaborate apparatus in the Hydraulic Laboratory of McGill University, for experimentation with jets of water (as to coefficients of efflux, form of jets and impact of jets on vanes and cups of various shapes); with methods of use and results obtained.

An illustrated abstract (ten pages of fine print) of Bazin's papers in the Annales des Ponts et Chaussées on experiments with weirs; including the phenomena of depressed, drowned and adhering nappes.

In connection, with flow in pipes, the formulæ of Darcy, Hagen, Thrupp, Reynolds, Lévy, Vallot, Manning, Tutton, Flamant, Foss and Lampe.

Many of the results obtained by Mr. C. H. Tutton in 1896 in his careful and extended collation, and logarithmic plotting, of the elements of some 1,000 recorded experiments on the flow of water in pipes; with diagrams and formulæ. 